\title{
TNRC6B Gene
}

National Cancer Institute

\section{Source}

National Cancer Institute. TNRC6B Gene. NCI Thesaurus. Code C134308.

This gene plays a role in RNA binding and RNA-mediated gene silencing. 